\title{
Carnivalesque and its All-Pervasive Influence in Caryl Churchill's Cloud Nine
}

\author{
Hassan Abootalebi \& Alireza Kargar \\ Ph.D student of English Language and Literature, Kharazmi University, Tehran, Iran. \\ Email:abootalebi2o1o@gmail.com \\ M.A in English Language and Literature, Lorestan University, Khorramabad, Iran. \\ Email: alirezakargar1984@gmail.com
}

\begin{abstract}
The current paper is an attempt to scrutinize and shed some light on Caryl Churchill's play Cloud Nine (1979) with the application of Mikhail Bakhtin's theories of carnival and carnivalesque explicated in his celebrated book Rabelais and His World (1984) which presupposes a world in which the flouting of, and challenging authority along with disrespect for, and disregard of, what is deemed sacred and valued are vital and instrumental, where individuals are liberated from any restrictions imposed on them outside carnival, and are permitted to pursue what pleases them without the least fear of being castigated, oppressed or interrupted by authorities. The selected work, as argued in the subsequent sections of the present article, presents a world where authority and social constructs as well as conventions are all undermined and mocked. What is thought of as truth is, therefore, mocked, and the characters are no longer restricted by imposed rules and regulations. It, however, celebrates the subversion and calling into question of gender roles and demonstrates how restrictive and oppressive these roles can be, and what it is like when one is not circumscribed by societal constructions and expectations, and is given the opportunity to enjoy themselves in an unlimited way. In the first act, everyone stands in an already pre-defined position, as expected by the authorities, where no transgression is tenable, and no one seems inclined to go beyond them. The second act, however, is set in London in 1979 and women are no longer restrained by rules, and the characters as a result grow. In what follows, the words carnival and carnivalesque will be first fully defined and elaborated on, and then applied to Caryl Churchill's Cloud Nine to illustrate the abovementioned claim.
\end{abstract}

Keywords: Mikhail Bakhtin, carnival, carnivalesque, Caryl Churchill, Cloud Nine

The principle of laughter and the carnival spirit on which grotesque is based destroys this limited seriousness and all pretense of an extratemporal meaning and unconditional value of necessity. It frees human consciousness, thought, and imagination for new potentialities.

(Bakhtin, Rabelais and His World)

\section{Introduction}

To begin with, it would be helpful to provide a succinct introdution to, and definition of, the words carnival and carnivalesque. Originally, carnival was a "feast observed by Roman Catholics before the Lenten fast began." Traditionally, meat was forbidden to be eaten during the Lenten fast. Carnival was thus the final occasion on which meat was allowed to be consumed before Easter. It, broadly defined, connotes an "occasion or seasons of revels, of merrymaking, feasting and entertainments" with the aim of disrupting or subverting of "authority; a turning upside down

(c) AesthetixMS 2020. This Open Access article is published under a Creative Commons Attribution Non-Commercial 4.o International License (http://creativecommons.org/licenses/by-nc/4.o/), which permits non-commercial re-use, distribution, and reproduction in any medium, provided the original work is properly cited. For citation use the DOI. For commercial re-use, please contact editor@rupkatha.com. 
of the hierarchical scale" (Cuddon 2013, p. 104). It is, therefore, a "type of performance, but this performance is communal, with no boundary between performers and audience", creating both a situation in which "diverse voices are heard and interact, and "an alternative social space, characterized by freedom, equality and abundance." Moreover, people, during carnival, were "reborn into truly human relations", which were not simply imagined but "experience breaking down conventions and enabling genuine dialogue." The concept of carnivalesque, Bakhtin proposed, is noticeable in certain works of literature in which the work aims at subverting 'authority' or flouting "social norms" by 'ribaldry' through "introducing a mingling of voices from diverse social levels." Traces of carnivalesque, says Bakhtin, are patently obvious in ancient, medieval and Renaissance writers, and recur in Dostoevsky's novels (Abrams 2005, p. 77). However, during carnival there is a "temporary suspension of all hierarchical distinctions and barriers among men and of certain norms and prohibition of usual life." It can be claimed that "an ideal and at the same time real type of communication, impossible in ordinary life is established" (Bakhtin 1984, p. 15).

The element of carnival in literature is 'subversive' disrupting 'authority' and introducing 'alternatives', being thought of as a sort of "liberating influence" which Bakhtin sees it as "part of the subversion of the sacred word in Reinassance culture." Rabelais, Bakhtin suggests, is a writer who employed carnival in certain of his works (Cuddon 2013, p. 104). The carnival spirit, he argues further, "offers the chance to have a new outlook on the world, to realize the relative nature of all that exists, and to enter a completely new order of things" (Bakhtin 1984, p. 34).

An important aspect of carnival is laughter. Bakhtin believes "carnival rituals are shaped on the basis of laughter." It has also "the power of making an object come up close...turn it upside down, inside out"( Pirnajmuddin \& Amani 2013, p. 108). Laughter, he says, "degrades and materializes." By degradation he means:

coming down to earth, the contact with the earth as an element that swallows up and gives bith at the same time. To degrade is to bury, to sow, to kill simultaneously, in order to bring forth something more and better" To degrade also means to concern oneself with the lower stratum of the body, the life of the belly and the reproductive organs; it therefore relates to acts of defecation and copulation, conception, pregnancy, and birth. Degradation digs a bodily grave for a new birth; it has not only a destructive, negative aspect, but also a regenerating one. To degrade an object does not imply merely hurling it into the void of nonexistence, into absolute destruction, but to hurl it down to the reproductive lower stratum, the zone in which conception and a new birth take place. Grotesque realism knows no other lower level; it is the fruitful earth and the womb. It is always conceiving. (Bakhtin 1984, p. 21)

What results from laughter is "parody that is subversive of authoritative discourses" (Pirnajmuddin \& Amani 2013, p. 108). The kind of parody related to the current discussion is the parody of gender roles and social constructs within a society. Carnival laughter is, according to Bakhtin (1984), a "festive laughter"; not a reaction of an individual to some event of "isolated comic". It is rather the "laughter of all the people". It is also "univesal in scope" being directed at everyone. The whole world is in its "gay relativity." This laughter is, Bakhtin claims, 'ambivalent', that is, it is "gay, triumphant" and simultaneously 'mocking and 'deriding'. It "asserts and denies, it buries and revives." Such is the laughter of carnival. This laughter is also directed at "those who laugh." The reason is that these people are part of "the wholeness of the world." They are, in fact, not complete and perfect. They, as it is true of other people, "die and are revived and renewed." 
This is, says Bakhtin (1984), one of the main differences of the "people's festive laughter" from that of modern times which is "pure satire"(pp.11- 12).

Carnivalesque, moreover, implies "redeployment or counter production of culture, knowledge and pleasure." With regard to its "multivalent oppositional play", carnivalesque "refuses to surrender the critical and cultural tools of the dominant class." Hence it can be regarded as "a site of insurgency". It is thus free from "socially imposed valuse and taboos." It contains elements that "promote change and freedom" highlighting the "relativity categories" in structures within a culture (Petrescu 2018, p. 109). Carnival, therefore, is, Bakhtin (1984) reminds us, "a second world and a second life outside officialdom, the people's second life, organized on the basis of laughter." It is, in other words, "a festive life" (p. 8). It is also characterized by a "temporary liberation from the prevailing truth and from the established order" tending towards the turning upside down of "hierarchical rank, privileges, norms, and prohibitions." Bakhtin even goes further by claiming that carnival was the

"true feast of time, the feast of becoming, change and renewal. It was hostile to what was immortalized and completed" (p. 10).

Rank was of great import in "official feasts" where every individual was required to "appear in the full regalia of his calling, rank, and merits and to take the place corresponding to his position." It was, therefore, a "consecration of inequality." During carnival, however, everyone is considered "equal'. A form of "free and familar contact" reigns among people who were often divided by the "barriers of caste, property, profession and age." Hence, a true human relationship is reborn. Consequently, the suspension and inversion of all "hierarchical precedence" during carnival, was instrumental (Bakhtin 1984, p. 10). During carnival "everything conventional and official is mocked and revered and seen as happliy grotesque" (Pirnajmuddin \& Amani 2013, p. 106). Thus 'dogma', or 'authoritarianism', or even "narrow-minded seriousness" does not exist because a "second life" is constructed, considered a parody of the "extracarnival life" or to put it another way, a "world inside out" (Bakhtin 1984, p. 11). Furthermore, in carrnival, Bakhtin (1984) claims, "the new mode of man's relation to man is elaborated." One of the most distinctive features of this "relation is the unmasking and disclosing the unvarnished truth under the veil of false claims and arbitrary ranks" (p.1). A final point concerning carnivalesque which is worth citing here is that characters are, says Bakhtin (1984), enabled to express themselves, to articulate their feelings freely which are not "controlled by the author to represent the author's viewpoint." They are, indeed, not only "objects of the author's word, but subjects of their own directly significant word as well." This quality, he maintains, is "a kind of dynamic and liberating influence" which leads to conceptualizing reality and "giving freedom" to individuals. By doing so, it subverts "the type of monologic discourse" characteristic of a large number of nineteenth-century works (Cuddon 2013, p. 105).

\section{Discussion}

Caryl Churchill's most internationally acclaimed and celebrated work Cloud Nine (1979), written in two acts has since its publication been subject to analysis and investigation mostly from feminist and colonial perspectives intending to make a connection between sexual and colonial oppression. The current paper, however, sets out to put it under furthur examination in the light of Mikhail Bakhtin's famed notions of carnival and carnivalesque expounded on in his book Rabelais and His World (1984) in an attempt to find out the elements associated with the abovementioned theories to demonstrate the manner in which authority and power structures are all 
undermined and mocked by individuals, and what it is like when people are no longer restricted by rules and conventions.

The play, as Caryl Churchill herself writes in the introduction, is to suggest the "parallel between colonial and sexual oppression", often referred to as "the colonial or feminine mentality of interiorised repression." The first act, therefore, is set in "Victorian Africa" and is a structured, male dominated society. The second act, however, takes place in "London in 1979" having a "looser structure" in which "more energy comes from the women and the gays," and the characters change a little bit "for the better." If men find it difficult to "keep control" in act one, they find it difficult to "let go" in act two (Churchill 1996, ix).

In the first act of the play everything and everyone stands in an already pre-defined position, precisely as expected and assigned by the authorities. No one seems inclined to go beyond them. This is patently obvioust from the very start of the play where Clive, a colonial administrator, introduces himself and his wife, Betty:

we serve the Queen wherever we may roam. I am a father to the natives here, and father to my family so dear...My wife is all I dreamt a wife should be, and everything she is she owes to me. (Churchill 1996, p. 9).

Similarly, Betty puts it clearly that she is expected to follow her society's norms:

I live for Clive. The whole aim of my life. Is to be what he looks for in a wife. I am a man's creation as you see, and what men want is what I want to be...Clive is my society. (pp. 910)

As a furthur illustration, Joshua, the black servant, is exactly what the white expect him to be:

"I hate my tribe. My master is my light. I only live for him. As you can see, what white men want is what I want to be" (p. 3).

He even when learns of his parents' death is reluctant and disinclined to attend their funeral because "my mother and my father were bad people" (p. 3). What is more, Clive attempts to teach his son Edward "to grow up to be a man" (P. 4), so that he could emulate the manner he behaves, but for Edward it is extremely difficult to follow in his father's footstepsts, and to be what his father demands him to be. The above-mentioned examples illustrate a world in which people act according to what they are supposed to, where men have their own duties and women have theirs as well.

Although dissatisfied with, and sick and tired of, the kind of existence she is leading with Clive on the one hand, and being so eager to join and accompany Harry the explorer on the other, Betty remains effete and unable to disentangle herself from her current, pathetic situation and to pursue Harry; to do what pleases her since she is "a mother, and a daughter, and a wife" (p. 14). Even when Clive becomes aware of her inclination and willingness towards Harry, he tries to remind her of her responsibilities for the family and her husband, and interestingly Betty acknowledges her wrongdoing and gives Clive a categorical assurance that nothing of the same kind will happen again:

Betty I'm sorry, I'm sorry. Forgive me. It is not Harry's fault, it is all mine. Harry is noble. He has rejected me. It is my wickedness. I get bored, I get restless, I imagine things. There's something wicked in me, Clive.

Clive I have never thought of you having the weak qualities of your sex, only the good qualities. 
Betty I am bad, bad, bad. Forgive me.

Clive It was a moment of passion such as women are too weak to resist. But you must resist it, Betty, or it will destroy us...Yes I do forgive you. But I can't feel the same about you as I did. You are still my wife and we still have duties to the household.(p. 24)

Betty, being subjected to the "destructive male fantasy and its constant supervision" is, as a result, deprived of any power and is coerced into submitting to her husband's "patriarchal values", and is regarded as the embodiment of the "female construction by patriarchy"(Yilmaz 2011, p. 66). She, indeed, possesses no voice and value and acts entirely as an obedient, dutiful wife and is completely trapped within societal regulations and attitudes towards women and the role they are supposed to play in both family and community. She is even reminded by her mother of the merits of remaining patient and subservient and not to complain:

"Betty you have to learn to be patient. I am patient. My mama was very patient" (Churchill 1996, p. 32).

Hence, Clive can be thought of as the "representative of patriarchy" and also an "oppressive regulation of society" who "embodies the anxiety felt by the heteronormative world" and the one who aims at "securing his place" through creating a "violent hierarchy between himself" and those who do not conform to a "heterosexual societal structure." Her incessant insistence on rendering homosexuality "invisible and pathological" is rooted in his "motivation to define himself as its ultimate opposite" and to perpetuate his status (Yilmaz 2011, p. 61).

Edward, despite possessing biologically male attributes, adopts feminine qualities and shows a propensity for having and playing with dolls which is typically and conventionally associated with girls, and defends himself by claiming:

"she doesn't love Victoria and Victoria doesn't love her. Victoria never even plays with her" (Churchill 1996 , p. 41).

While Victoria, his younger sister, is reluctant to do so. Edward is, however, castigated by Ellen and severely reproached by his mother and his grandmother for his proclivities: "Victoria will learn to play with her" (p. 41). He is also reminded and warned of its consequences: "You must never let the boys at school know you like dolls. Never, never. No one will talk to you, you won't be on the cricket team, you won't grow up to be a man like your papa" (p. 36). Teaching Edward and Victoria to behave according to norms, Maud, Gobert (2014) writes:

serves as a surrogate for Ellen, whose role as governess makes plain her disciplinary function. But Maud ultimately surrogates the larger ideological force, patriarchy, that has forbidden Edward to play with the doll in the first place. For Edward's indoctrination into manliness clearly prepares him to one day inherit Clive's patriarchal and, relatedly, colonial duties. (pp. 86-7)

Edward is even supposed to have deep respect and admiration for, and love of, his father not just because he admires his father and his father deserves it, but merely because Clive is his father and Clive himself loved his father, and is scolded by his father for spending time being in the community of women and is supposed to have more contact with men not women. Therefore, circumstances oblige him to stay away from the company of women and act according to already defined masculine assumptions and expectations. Edward at this point ostensibily retracts his interest in women and dolls: "I don't like women. I don't like dolls papa" (p. 36). 
Another character worth mentioning here is Ellen, the governess. She is attracted to, and infatuated with, Betty but is not liberated to pursue what pleases her, and is supposed to suppress her feelings and proclivities. Thus, as a result of being reminded by Betty of the advantage of having a husband on the one hand, and of getting married as something that has nothing to do with enjoyment on the other, Ellen is dissuaded from thinking of homosexual relationship and is instead directed to ponder over heterosexual one. She is ultimately forced into marring Harry:

Ellen I want to stay with you forever.

Betty If you go back to England you might get married, Ellen. You shoudn't despair of getting a husband.

Ellen I don't want a husband. I want you. Betty, what happens with a man? I don't know what to do.

Betty Ellen, you're not getting married to enjoy yourself. (p. 41)

The above-mentioned examples underline and highlight the importance assigned to longperpetuated notions of what is thought of, and regarded as, conforming to, or violating from, socially constructed norms. As observed and cited above, individuals are required to behave according to social and conventional codes of masculinity and femininity and any deviation and transgression from accepted social norms and deeply-held beliefs is deemed to be unethical and immoral which needs to be immediately suppressed and consigned to oblivion.

In the second act, however, the situation is completely different. Wheras in act one every individual is required to behave according to social and cultural conventions, in act two there is a celebration of homosexuality and mocking of authority and norms associated with the structures of power. "All the symbols of carnival idiom", Bakhtin (1984) maintains, "are filled with this pathos of change and renewal, with the sense of the gay relativity of prevailing truths and authorities"( p.11). This is easily noticeable in the way characters treat established truths in act two. Edward, for example, can freely express his homosexuality, incestuousness and at the same time his attraction to women: "I'd rather be a woman. I wish I had breasts like that, I think they're beautiful...I am sick of men. I think I am a lesbian.", and doing such chores conventionally associated with women as taking care of children and cooking:

Gerry Whose wife are you now then?

Edward Nobody's. I don't think like that anymore. I'm living with some women.

Gerry What women?

Edward It's my sister, Vic, and her lover. They go out to work and I look after the kids.

Gerry I thought for a moment you said you were living with women.

Edward We do sleep together, yes. (Churchill 1996, p. 51)

When learned of his son being like the one mentioned above, Betty comes to accept it as Edward is pleased and satisfied with his current situation and is herself attracted to Gerry, his son's lover, although her mother constantly warns her of the ramifications of not having a husband and what it is like to "be unprotected" and being "alone in the world." However, Betty intends to find her way as a "divorced, sexually active, mature woman" and tries to "understand her children, gay Edward and lesbian-in-tansition Victoria"(Aston \& Diamond 2009, p. 28) in an effort to live a life from scratch free from imposed, constructed norms and conventions. 
Victoria, despite being married and having a child, is attracted to Lin (a lesbian woman) and decides to live with her as a sexual partner, and interestingly Martin, her husband, when discovers this does not try to dissuade her of doing so. Rather he wants her to leave behind her family and go her own separate way:

"You're the one who's experiencing with bisexuality, and I don't stop you, I think women have something to give each other. You seem to need the mutual support. You find me too overwhelming" (Churchill 1996, p. 63).

Lin and Victoria, therefore, inspite of the fact that they possess feminine attributes and the "heterosexual society's expectations from them", they are "sexually drawn together and commence a relationship as homosexual partners" (Joodaki \& Bakhshi, 2013 p.129).

One of the salient features of carnivalesque is that "differences between superiors and inferiors", Bakhtin (1984) maintains, "disappers and all draw close to each other" (p. 246). It neither embraces the "authority of males" nor repudiates "the power of women" who are conventionally considered 'inferiors' (Mirmousa 2014 p. 3l). It rather liberates itself from the "prevailing view of the world, from conventions and established truths, from clichés, from all that is humdrum and universally accepted" (p. 142). A "second world and a second life outside officialdom" a world where "all medieval people participated more or less, in which they lived during a given time of the year" (Bakhtin 1984, p. 6) is thus constructed with the aim of the parody of the community presented in the first act in which no deviation from long-standing norms was permitted. There is a mocking of gender constructions and celebration of homosexuality which is strictly oppressed and opposed in act two. In order to "denaturalize and destabilize and uproot the pervasive assumptions about natural or presumptive heterosexuality", Edward is played by a woman as that differentiation between "femininity and masculinity" is blurred. The discrepancy between "outward appearance and the inward essence" connotes the constructiveness of gender and 'deceptivensess' as well as "unreality of apperance” (Joodaki \& Bakhshi 2013, p.130).

The play, as mentioned by Aston (2009), "captured tumultuous project of sexual experiment in its utopian aspect" and "confusion and pain of rapid social change". It was evidently 'utopian' and simultaneously it "laid out the various conflicts and unresolved contradictions among radical people" who attempted to "rethink and live new kinship relations." Churchill challenges "notions of fixed identity" as well as "normative sexual identifications." Moreover, "her take on feminist debates", Aston (2009) maintains, concerning "essentialism and social construction" is meant to suggest the possibility for individuals to "transform themselves into new, non-normative identities." In addition, it implies the "pain and confusion" regarding "gender ambiguity and radical socio-sexual change" in a variety of issues including "class, sexual, racial and generational differences" (pp. 27, 29). Indeed, all the characters emerging in the second act enjoy a free sexual life and what societal rules and regulationns demand them is a matter of total indifference to them. Put it another way, they approach authority and power structures with a degree of scepticism and anything conventional and official is mocked and reversed. Therefore, a second life "outside officialdom" liberated from prevailing truths and conventions is created which is characteristic of what Mikhail Bakhtin recognizes as carnivalesque. The constructed world in act two is far more pleasing and satisfactory than the one in act one where individuals are enabled to re-examine and suvbert long-held cherished beliefs. 


\section{Conclusion}

As argued and observed above, Caryl Churchill, by depicting two entirely disparate worlds in two acts in his famed play Cloud Nine, endeavors to attract attention to constructiveness of gender roles and restrictiveness of established norms by those in power and to underline the significance of liberating oneself from these long-perpetuated and cherished norms which only suit the authorities but circumscribe and erode individuals' powers and rights who are unable to disentangle themselves from restrictive conventions and expectations. Wheras in act one every person is required to act according to what society and the rules within it allow them, where no deviation from constructed truths is tenable and acceptable, in act two conditions do not conform to the ones in the previous one in which the relative nature of what was considered truth is undermined and mocked, and the characters are enabled to do what pleases them without the least concern for social rules and regulations. Consequently, a real type of communication impossible in act one occurs. Having read the selected work in the light of Mikhail Bakhtin's theory of carnivalesque, we as readers are capable of placing the play within a broader framework and apprehend the yet ignored aspects of it.

\section{Works Cited}

Abrams, M.H. A Glossary of Literary Terms. Canada: Wadsworth Cengage Learning, 2005. Print.

Aston, E., Diamond, (Ed). The Cambridge Companion to Caryl Churchill, 2009. Print.

Bakhtin, M. Rabelais and His World. Trans. Helene Iswolsky. Bloomington: Indian University Press, 1984. Print.

Churchill, C. Plays: One. London: Methuen.1996. print.

Cuddon, J.A. A Dictionary of Literary Terms and Literary Theory. wiley-Blackwell, 2013. Print.

Gobert, R.D. The Theatre of Caryl Churchill. Bloombsbury Methuen Drama, 2014. Print.

Joodaki, H., Bakhshi, P. “The Collapse of Heterosexism and Phallogocentrism in Caryl Churchill's Cloud Nine." CS Canada, Studies in Literature and Language, 2013. Print.

Mirmusa, S. “Bakhtinian's Carnivalesque in Angela Carter's The Magic Toyshop, Several Perceptions, Nights at the Circus and Wise Children." 3L: The Southeast Asian Journal of English Language Studies, 2014, vol2o(2): 141-154. Print.

Petrescu, A. "A Bakhtinian Reading of Caryl Churchill's Feminist Discourse in Top Girls. International Journal of Multidisciplinary Research Review", 2018. Print.

Pirnajmuddin, H., Amani. “The Carnivalesque in Nathaniel Hawthorne's The Scarlet Letter." Epiphany, Journal of Transdisciplinary Studies, 2013. Print.

Yilmaz, N. Gender Politics and Feminism in Caryl Churchill's Cloud Nine. University of Barcelona, 2011. Print. 